\title{
F09-(3) 機能性流体・インテリジェント熱源としてのプラズマ利用
}

秋田県立大学武田。紘一

\section{1. 煞プラスマ利用の视点}

産業プロセスに利用されるブラズマは弱電離状態で、電子とイオンの荷電粒子と電離し ていない中性粒子とで構成される。栗成粒子間で密にエネルギーのやり取りがなされてい て、局所的なスケールでは熱平衡状態にあるとみなせる場合，この集団を熱プラズマと呼び、 エネルギーのやり取りが粗な非平衡プラズマと区別される。ここでは熱プラズマに焦点を あてて話しを進める。

表 1 に熱プラズマの特徴をまとめて示した。

表 $1 \quad$ 熱プラズマの特徵と代表的な物性值

\begin{tabular}{|c|c|c|c|}
\hline 徵 項 目 & 説 & 代表的数值等 & 比較数值 \\
\hline $\begin{array}{l}\text { 高温・高エネルキ } \\
\text { 一密度 }\end{array}$ & 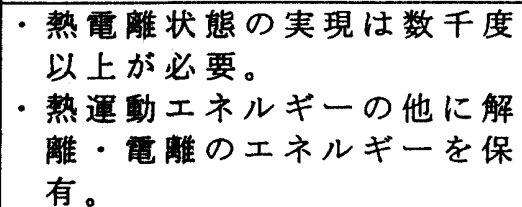 & $\begin{array}{l}\text { 温度 }(\mathrm{T}): \\
\text { 数千〜3 万 } \mathrm{K} \\
\text { エンタルピー } \\
10^{4} \sim 10^{5} \quad \mathrm{~kJ} / \mathrm{m}^{3}\end{array}$ & $\begin{array}{l}\text { 然焼 炎 } \\
\mathrm{T}<3000 \mathrm{~K} \\
\mathrm{H}= \\
10^{3}-10^{4} \mathrm{~kJ} / \mathrm{m}^{3}\end{array}$ \\
\hline 電磁流体 & $\begin{array}{l}\cdot \text { 荷電粒子をふくむ集合体 } \\
\text { ・全体として電気的中性 }\end{array}$ & $\begin{array}{c}\text { 荷電粒子密度 }\left(\mathrm{n}_{\mathrm{e}}\right): \\
10^{17}-10^{19} / \mathrm{cm}^{3} \\
\text { 導電率 }(\rho): \\
10^{-3}-10^{-5} \quad \Omega \mathrm{m}\end{array}$ & $\begin{array}{l}\text { 金属 } \\
\mathrm{n}^{\mathrm{e}}=10^{23}-10^{24} / \mathrm{cm}^{3} \\
\rho=10^{-6}-10^{-7} \Omega \mathrm{m}\end{array}$ \\
\hline 高熱伝導率媒体 & $\begin{array}{l}\text { - 移動エネルギーは熱運動エ } \\
\text { ネルキーの他に再結合のエ } \\
\text { ネルギーを含む }\end{array}$ & $\begin{array}{l}\text { 熱伝導率 }(\sigma): \\
\text { (水素プラズマ) } \\
50 \sim 1500 \mathrm{~W} / \mathrm{m} . \mathrm{K}\end{array}$ & $\begin{array}{l}\text { 常温水素ガス } \\
\sigma=0.2 \mathrm{~W} / \mathrm{m} \cdot \mathrm{K}\end{array}$ \\
\hline $\begin{array}{l}\text { 反応活性・ } \\
\text { 寄囲気制御 }\end{array}$ & $\begin{array}{l}\text { ·解離原子、電子、正イオン、 } \\
\text { 負イオンの存 } \\
\text { ・高温場での高速反応 } \\
\text { ・電気加熱による清浄突囲気 }\end{array}$ & & $\begin{array}{l}\text { 燃焼高温場 } \\
\text { 酸素、燃焼 } \\
\text { 生成物の存在 }\end{array}$ \\
\hline 高粘性 & $\begin{array}{l}\text { （高粘性ただし電離度が進む } \\
\text { と粘性低下） }\end{array}$ & $\begin{array}{l}0 \text { 粘 性 }(\eta): \\
0.1-0.3 \mathrm{cP}\end{array}$ & $\begin{aligned} \text { 常温気体 } \\
\eta=0.01 \mathrm{cP}\end{aligned}$ \\
\hline 光放射 & $\begin{array}{l}\text { - 励起粒子種からの高輝度光 } \\
\text { 放出 } \\
\text { 波長幅 : 外線〜赤外線 }\end{array}$ & $\begin{array}{l}\text { 特定波長、不連続 } \\
\text { スペトル }\end{array}$ & \\
\hline 空間的非平衡 & $\begin{array}{l}\text {-急峻な温度勾配の存在 } \\
\text { (高温淮安定相のクエンチン } \\
\text { グ) }\end{array}$ & $\begin{array}{l}\text { 温度勾配 } \\
10^{6}-10^{7}\end{array}$ & \\
\hline
\end{tabular}

\section{2. 熱プラズマの利用研究}

筆者が取り組んでいる熱プラズマ応用技術開発の例を以下に紹介する。 


\section{1 電磁流体的性買の利用}

(磁気制御プラズマアーク)

直流アークによりプラズマを形成すると アークの熱的・電磁的ピンチ効果によりア ーク柱は細く絞られ局所的にエネルギー密 度の高い熱源となる。アークに外部より磁 界を作用させ電磁力によりアークの形状を 制御する技術を開発している。交流磁界印 加してアークを高速で摇動することにより 幅の広い熱源を作ることが出来る（図 1)。

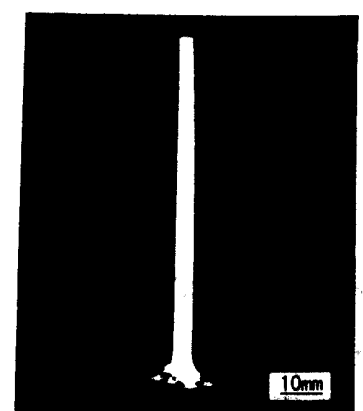

(a)磁場無しアーク

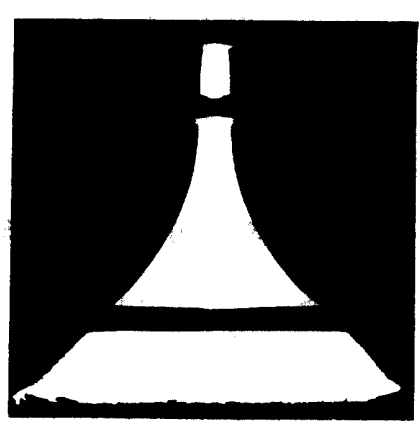

(b)磁場印加アーク

\section{2 化学的活性の利用 (フロンの分解・無害化 ${ }^{1}$ )}

フロンはオゾン層を破壊することが明ら かになり、製造が制限されている。高周波 プラズマ中に水とフロンを吹き込みフロン を分解して無害化する技術を開発した。 プラズマの高温によりフロンを原子状にば らばらにした後、冷却過程で有害物が再合 成されぬよう空間的に急峻な温度勾配を利 用する。フロン 12 の分解、無害化反応は 次式でしめされる。

$$
\mathrm{CCl}_{2} \mathrm{~F}_{2}+2 \mathrm{H}_{2} \mathrm{O} \rightarrow \mathrm{CO}_{2}+2 \mathrm{HF}+2 \mathrm{HCl}
$$

分解排ガス中のダイオキシン濃度は検出限 界值以下である。

\section{3 インテリジェントなアーク熱源利用（金属表面活性化処理）}

真空アークの陰極点は、酸化物（炭化物、窒化物）と金属が共存する表面では酸化物を自らが探し だし、酸化物のみを選択的に繁発除去し（仕事関数の差による作用）、活性で清浄な金属表面を作り出 す。さらにアーク電圧は酸化物上に存在するときは低く、金属上では高くなる性質を有する。真空ア ークを金属表面のクリーニング処理に用いると、污れ部（非金属部）を自動的に検出するセンサー機 能、見つけた污れのみを優先的に除去していく 選択処理機能、および処理表面の清浄化作業が 終了したとき電圧上昇によりクリーニング処理 の終了をしらせる情報発信の機能をも活用出来 る。真空アーク陰極点は他の熱源には見られな いインテリジェントな熱源であるといえる。 図 3 にアーククリーニングの一例している。複 雑形状に対しても表面の溶損無しに処理可能で ある。

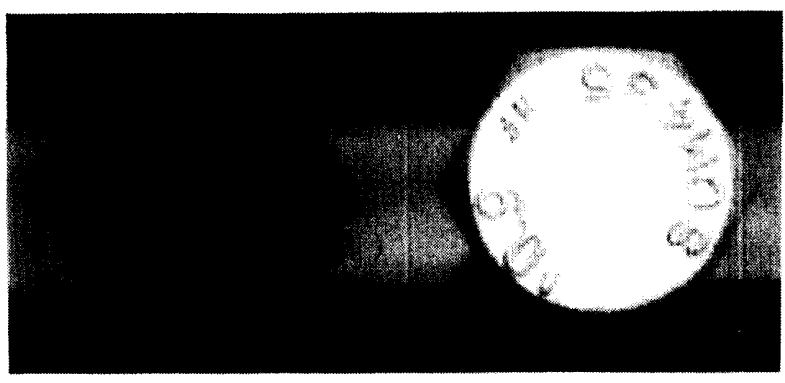

(a)未処理

(b)アーク処理

図 3 アーク・クリーニング処理ボルト

\section{文献}

(1) S.Takeuchi, K.Takeda et al: Plasma Sources Sci. \& Technol., 2(1) (1993), pp.63-66. 